Vitae

Yulia Artemova - second year postgraduate of the specialization 035 "Philology" of the department of Ukrainian language named after prof. Kalenyk Shulzhuk of Rivne State University of Humanities. Sphere of her scientific interests are linguocultural studies, cognitive linguistics, cognitive semantics, linguoconceptology, text linguistics.

Correspondence: jartemova18@gmail.com

Надійшла до редакції 25 березня 2019 року.

DOI 10.31558/1815-3070.2019.37.14

УДК 81 '42-028.61

\title{
РЕГУЛЯТИВНІ СТРАТЕГІЇ Й ТАКТИКИ В СУЧАСНІЙ УКРАЇНСЬКІЙ ХУДОЖНІЙ ПРОЗІ
}

Ідеться про регулятивну стратегію як вектор мовленнєвої поведінки адресанта, щзо передбачає спеціальне оброблення художнього повідомлення з метою оптимального порозуміння з адресатом в умовах асинхронної комунікаціі. Запропоновано класифікацію регулятивних стратегій сучасного художнього прозового тексту, з'ясовано їхні основні та допоміжні тактики. Продемонстровано, щуо регулятивне структурування тексту передбачає імітацію усного спілкування автора з читачем.

Ключові слова: літературна комунікачія, комунікативна стратегія, регулятивна стратегія, регулятивна тактика, регулятивний прийом.

Літературна комунікація є складним психічним процесом. У його основі - сприйняття не так фізичних подразників - друкованих літер, пунктуаційних знаків, площинного розташування компонентів тексту тощо, як закодованої в них інформації. Дешифрування художнього повідомлення, безперечно, зумовлене пресупозицією, рівнем асоціативного мислення й уяви, внутрішньою активністю реципієнта. Воно індивідуально-суб'єктивне, неповторне, варіативне, водночас передбачає інваріантний складник, генерований, з одного боку, фабулою твору, зображеним у ньому предметним світом і персонажами, з іншого - системою продуманих автором поетапних мовленнєвих дій, що є тактиками його регулятивної стратегії.

Регулятивна стратегія входить до загальної комунікативної стратегії тексту. За концепцією О. Іссерс (Issers), яка набула особливого поширення в лінгвістиці, комунікативні стратегії диференційовані на основні та допоміжні. Основні стратегії - семантичні, когнітивні - пов'язані із впливом на концептуальну свідомість адресата. Допоміжні стратегії зумовлені ситуацією, вони контролюють перебіг спілкування і привертання уваги читача до інформативно значущих фрагментів тексту. В усному спілкуванні таку роль здебільшого виконують риторичні, діалогові комунікативні стратегії, у художньому ж тексті цю функцію перебирають на себе регулятивні стратегії, що послідовно маркують основні етапи комунікативного процесу - кодування, вибір каналу зв'язку, передачу інформації, декодування. Отже, регулятивна стратегія постає окремим вектором мовленнєвої поведінки адресанта, маніфестує спеціальне художнє оброблення повідомлення з метою ефективного взаєморозуміння 3 адресатом в умовах асинхронного спілкування та відображає евристичну інтенційну програму планування дискурсної взаємодії автора з читачем, спрямованої на трансформацію моделі світу останнього.

Регулятивні стратегії візуалізовані за допомогою регулятивних тактик, що грунтуються на мовленнєвих уміннях, комунікативній компетенції, мотиві та інтенції автора. Тактику співвідносять із певним етапом утілення стратегії, на якому реалізують те чи те глобальне або локальне комунікативне завдання. Якщо стратегію асоціюють із метою, то тактику - із «практичним засобом руху до <... мети» (Klyuev 43). Окремі регулятивні тактики, їх перехрещення чи накладання стають платформою для реалізації основних комунікативних стратегій художнього тексту. Репрезентованість регулятивних тактик у художньому тексті-дискурсі може набувати таких форм, як монотактичність (регулятивна стратегія об'єктивована використанням однієї тактики) та політактичність (регулятивна стратегія передбачає кілька різних тактик). Цілеспрямований набір регулятивних стратегій та їхніх тактик завжди підконтрольний глобальному намірові й репрезентує регулятивне планування тексту. Регулятивне планування художнього тексту передбачає транслювання якнайточнішої інформації, сприймання якої залежатиме від характеру стимулювання пізнавального інтересу в реципієнта та його активності. Із цією метою регулятивне структурування тексту зорієнтоване на імітацію усного спілкування, створення ілюзії синхронної комунікації.

Регулятивна стратегія художнього тексту стала об’єктом студіювань лише нещодавно (див. праці, наприклад, Н. Болотнової, О. Асланової, Н. Камнєвої, Л. Карепіної, Н. Петрової, К. Шмугурової та ін.). Її специфікою беззаперечно визнано зорієнтованість на досягнення кооперативного результату. За ознакою дієвості (Кhауm 156174) регулятивну стратегію номіновано гнучкою, здатною вибудовувати різну лінію мовленнєвої поведінки продуцента: залежно від контекстних умов він або порушує принципи та норми стереотипної художньої комунікації, або прагне дотримуватися їх. Цей різновид комунікативної стратегії варто оцінювати й на тлі активно

(C) Галаур С., 2019 
студійованої останнім часом концепції інтимізації тексту (А. Корольова, Т. Космеда, А. Палійчук, Т. Радзієвська, І. Сирко та ін.) - формування «ефекту близькості, дружби та безпосереднього емоційно-інтелектуального спілкування автора $з$ читачем» (Levchuk 123).

Чіткого ранжування регулятивних стратегій сьогодні ще немає. Складність, різноаспектність, нерегламентованість художньої комунікації спричинює проблему вибору оптимальних критеріїв для диференціації цих стратегій. Долучитися до їхніх пошуків та запропонувати власне бачення регулятивної стратегічності в художньому тексті й стало метою дослідження.

Оптимальне оформлення в художньому прозовому тексті мовленнєвого акту, що найадекватніше відповідає конкретній комунікативній ситуації, детермінує такі регулятивні стратегії:

1) послідовно-конвергентну,

2) парадоксально-контрастивну,

3) мовної гри,

4) мовленнєвого портретування,

5) адресованості,

6) мовчання.

Послідовно-конвергентна регулятивна стратегія. Продуктивною регулятивною стратегією в сучасних українських прозових текстах є послідовно-конвергентна. Саме вона найповніше відображає процес змістового сприйняття й рівневість оброблення мовленнєвого сигналу (Zimnjaja 9). Багатократно актуалізована у процесі текстового розгортання ситуація, безперечно, створює умови для адекватного розуміння читачем естетичного змісту твору. На думку Б. Ларіна, «послідовне накопичення <..> концентрує увагу на одному стрижні думки, спонукає слухача (читача) черпати фантазійні можливості представленої теми й викликає інтелектуальну емоцію упізнання непередбаченої схожості змісту в різних зворотах мови». Такі мовленнєві варіації змісту, розвиває далі цю думку науковець, створюють ефект «змістового відлуння», що, зі свого боку, є умовою ліричного враження (Larin 424). Наприклад, у романі Є. Мельниченко «І засяє сонце» порушена проблема «вкрав гроші у Неньки» розв'язується через зображення жахливого стану сільських доріг - «самі вибоїни, сльота і калюжі». Лексеми «послизнутися» й «упасти» та їхні синонімічні варіанти, послідовно вживані в різних контекстах і ускладнені додатковим змістом, чітко оприявлюють авторську позицію. Напр.: [Микита] щзойно вийшов з хвіртки $і$ тількино ступив на дорогу, як послизнувся $і$ звалився у багнюку, що ї̈ було повно навкруги; Юхим вийшов із хвіртки, ступив два кроки, послизнувся $і$ бухнувся в калюжу; Юхим рушив до иеркви - вклонитися святому місцюю, та послизнувся і впав у калюжну сльоту; Юхим ще деякий час ганяв чортиків з мавками, а потім, роблячи дуже складний маневр у калюжі, впав у дуже глибокому ї̈ місиі і вже не зміг піднятися - якась непереборна сила вхопила його і поглинула.

Основними тактиками послідовно-конвергентної стратегії є мікроконтекстний та макроконтекстний повтор у всіх його версіях. Високою активністю вирізняється також тактика конвергенції. Її кумулятивний ефект формують нагромаджені в одному місці тексту спеціальні регулятивні засоби - стилістичні прийоми, які однофокусно, проте багатогранно конкретизують якусь реалію художнього світу: Твій голос. Твій доторк. Усе розпадається на фрагменти. Усе розпадається на циитати. Якась музика. Якийсь сон. Якийсь сум. Чи ти навчилася спати? Співай мені, співай. Конверти, цикорій, зима, прожилки. Ранкова кава. Думаю про тебе весь час. Мусимо бути окремо. Аж поки все не скінчиться (асонанс, алітерація, повтор, синтаксичний паралелізм, парцельовані конструкції) (Ю. Іздрик. Подвійний Леон). Прозорість авторської інтенції досить часто досягається аплікацією до тактик, описаних вище, тактики позиціювання, візуалізованої через використання заголовка тексту, епіграфа й наступного розвитку їхнього змісту в самому тексті. В оповіданні А. Трошиної «П'ять воронів на даху», зосібна, числівник п'ять, винесений у заголовок та несподівано поєднуваний у тексті з іншими іменниками - n'ять автобусів, n'ять горішків, - урешті-решт набуває чіткого образу: пятірка універсальна - символізує органи чуття людини: зір, слух, дотик, нюх, смак. Варто додати, що послідовно-конвергентна стратегія виявляє потенційні можливості вербалізації ключових концептів художнього твору.

Парадоксально-контрастивна регулятивна стратегія. Однією з домінантних рис виразності твору, його комунікативної спрямованості є контраст. Його вналежнюють до явищ психологічного рівня, способів упливу на сприйняття реципієнта, який у композиційно-стилістичному принципі розгортання мовлення, базованому на різко вираженій протилежності, виявляє, за твердженням Н. Грині, імплікації, нову конотативну та денотативну семантику, виразніше маркує контекст, авторську позицію, долучається до асоціацій із позатекстовим середовищем (Hrynya 87-90). За нашими висновками, парадоксально-контрастивна стратегія в художньому тексті не поступається послідовно-конвергентній. Взаємне протиставлення зіставлюваних на синтагматичній осі одиниць, що врешті-решт актуалізує парадоксальні значення у процесі текстового розгортання, може бути спостережене в тактиках фонетико-акцентуаційного, лексико-акцентуаційного, граматико-акцентуаційного та графіко-акцентуаційного контрастування. Оповідання П. Куща «Кіт Мишко», для прикладу, побудоване на семантичній опозиції «тепло - холод». Тепло для білого огрядного пухнастого кота Мишка - це голос хазяйки баби Марини, грубка, запас дров на зиму, про які піклувалася баба і рубати які «він з поважних причин не міг», дві пластикові плямки в постелі, одна $з$ яких («був переконаний») для нього, ковдра, зігрівання «у погоні за мишами», пес Пірат. Аби звернути особливу увагу читача на лексему «те-е-е-е-е-е-плої» (ковдри, під якою Мишко «муркотів від задоволення»), автор застосував до неї графіко-акцентуаційне контрастування. Розповідь драматизована лексико-акцентуаційним контрастуванням, яке спостережене тоді, коли предметом звичних побутових розмислів кота стають неосмислені ним «штуки», що принесли холод та біду - «озброєні люди, котрі <...> кричали, що тепер будуть 
всіх захищати», «триколірні прапори» і «міни, які встигли скалічити кількох мешканців села та приїжджих, що хотіли знайти тут дрова».

Оскільки дубльовані фрагменти тексту здатні увиразнювати неповторювану інформацію, слід наголосити на постійній взаємодії парадоксально-контрастивної стратегії з послідовно-конвергентною та на виокремленні на їхньому тлі дифузної стратегії - послідовно-контрастивної.

Регулятивна стратегія мовної гри. Неабиякої популярності серед сучасних українських письменників набуває стратегія мовної гри. Спостерігаючи за авторською лінгвокреативністю, О. Земська переконалася в тому, що мовна особистість, висловлюючись незвично, може ставити перед собою несерйозні завдання - посилити невимушеність спілкування, розважити співрозмовника, водночас частіше вона використовує мовну гру для точнішого, глибшого й тоншого висловлювання, трансформації думки («Russkaya razgovornaya rech» 174-175). Стратегія мовної гри втілюється в різного роду тактиках усвідомленого порушення мовного канону, 3-поміж яких, зокрема, модифікація сталих виразів: Не клей дурня, прошу тебе. Замислено вмошуючи слухавку на місие, намагаюся уявити собі изього дурня, склеєного - із иелюлози необов'язкових слів? із крабових паличок нестримного сміху? із слюдяних плиток критики чистого розуму? (Ю. Іздрик. Подвійний Леон). Мовні девіації, до яких удаються адресанти художнього повідомлення, не випадкові, вони вибудувані за певними шаблонами, зорієнтовані на природні властивості мови, «балансують на межі норми» (Norman 9). Як зауважують Т. Космеда та О. Халіман, «мовець у своєму мовленнєвому креативі навіть не порушує чогось, а лише слідує мовним настановам і виправляє несправедливість, заповнюючи лакуни через відсутність готових засобів, доводячи мовну систему до умовної ідеальності, що мотивовано відповідними комунікативними потребами» (Kosmeda, Khaliman 18). Тактики, про які йдеться, інколи приречені на комунікативні невдачі, оскільки маніпулювання словом може бути незрозуміле адресатові, якщо його мовні та комунікативні компетенції не збігаються з авторськими. Щоб уникнути прикрих непорозумінь, письменники залучають до мовної гри інші тактики, найчастіше повтор, акцентуаційне контрастування.

Дія або парадоксально-контрастивної стратегії, або стратегії мовної гри, або тієї і тієї стратегій водночас можуть спричинити ефекти ошуканого очікування чи комічного шоку. Із метою першого ефекту читача «заманюють на прокладений, але неправдивий шлях» (Shevchuk 14), створюючи, наприклад, лексико-акцентуаційний контраст між двома сильними позиціями в тексті-заголовком і кінцівкою. Існує думка про те, що ошукане очікування є окремою стратегією (Arnold 56), водночас більшість науковців цей факт заперечує, оскільки, за їхніми враженнями, ошукане очікування слугує «пробудженню зацікавленості, приверненню інтересу, а не уваги адресата» (Moskovin 40). Другий ефект спотережений тоді, коли «номіноване явище, що зовні видається дивним, насправді виявляється зрозумілим і природним» (Kosmeda 57). Мовним жартом із механізмом комічного шоку можна вважати контамінацію - склеювання двох мовних одиниць: Хай він буде червоний чи білий, сірий чи жовтий, а якщзо попер на твою землю, то не питай у нього, щзо він думає робити далі, а покажи заброді, почім фунт свинцю на украӥнському ярмарку (В. Шкляр. Маруся) (показати, де раки зимують + почім фунт лиха).

Регулятивна стратегія мовленнєвого портретування. Метою мовленнєвого портретування є продукування мовної багатомірності тексту, здатної породжувати в художньому творі складний комунікативно-когнітивний простір. Ця загальна стратегія зреалізовується за допомогою двох стратегічних ліній - мовленнєвого портретування автора й мовленнєвого портретування персонажа. Обидві субстратегії зазвичай накладаються, маніфестуючись або в тактиці мовленнєвої опозиції, або в тактиці мовленнєвої поліфонії на рівні вербально-семантичного втілення мовної особистості автора / персонажа, пор.: 1) Отож з рідного містечка позникали всі краєзнавиі, музейники, викладачі історії, не кажучи - української мови, хотілося вірити, щзо всі вони вдало емігрували з Донбасу. ... Ходили, грюкали у двері, мобілізували на роботи: - Виході, трудоспособний, - побачили на порозі тата. - Давай, Паня, паняй, шевєлі булками і 2) Вона сиділа перед вікном, слухала дощ, гадаючи, щзо ие буде вірш про нього, однак поставала проблема: а яка рима годиться до слова «дощч»? Хіба щзо «хвощ»». Смішно? (Б. Жолдак. Партизанка Ася). Перша тактика дає змогу репрезентувати своєрідний «мовленнєвий паспорт особистості» автора чи персонажа, друга - психологізувати прозу, проте і та, і та мають очевидний регулятивний потенціал, оскільки демонструють внутрішню позицію щодо об'єкта зображення, яка видається читачеві прийнятливішою, зрозумілішою, ніж імперсоніфікована реєстрація побаченого чи почутого. Основні тактики стратегії мовленнєвого портретування часто інкорпорують тактики інших регулятивних стратегій.

Регулятивна стратегія адресованості. Постійно присутня в сучасній українській прозі стратегія адресованості переконує в тому, що в «кожному художньому тексті більшою чи меншою мірою майстерно прихований авторський волюнтатив, спрямований на читача» (Krupa 127). Основною тактикою цієї стратегії є моделювання діалогу з уявним читачем, що сприяє безпосередній, особистісно-контактній, а тому повноцінній перцепції змістової консистенції твору. Апеляція, ідентифікація, спонукання, читацька активність, інтертекстуальність та інтермедіальність як тактичні прийоми стратегії адресованості не лише встановлюють і підтримують контакт із реципієнтом, але й готують читача до сприйняття основної інформації: Уявімо, щзо все сталося саме так; Ніколи не приходте туди, де ви одного разу вмирали (Ю. Андрухович. Дванадцять обручів); Якщо вам чогось не хочеться робити - краще не робіть. Хоча нас змалку намагалися привчити до порядку, бути відповідальними й організовувати свій день. Але при цуьому ми втратили одну дуже важливу якість-розучилися чути себе (Т. Брукс. Бережіть янголів своїх). Маргінальними тактиками адресованості можуть бути повтор, контрастування, мовленнєве портретування, невербальне вираження змісту. Якщо основна тактика пов'язана з ідентифікувальною (номінування адресата за різноманітними критеріями, які реферують вікові, статеві, статусно-рольові характеристики адресата), вокативною (привернення уваги адресата до майбутнього викладу основної інформації), 
апелятивною (спонукання до уважного прочитання, спілкування) функціями їі лінгворепрезентантів, то неосновні тактики більше спрямовані на емоційний відгук адресата і створення таким способом сприятливого тла для донесення автором необхідних ідей.

У сучасній українській художній прозі спостережено конвергентно-дивергентне спілкування автора 3 читачем. Про конвергенцію йдеться тоді, коли адресант пристосовується до стилю спілкування адресата (масова, дитяча, юнацька література). Якщо ж він більше акцентує увагу на власному стилі мовлення, комунікація маркується дивергентними явищами (постмодерна література). I той, і той приклад демонструють, за твердженням Г. Джайлса та Т. Огей, психологічну реакцію продуцента (Giles, Ogay), який бажає зацікавити своїм твором обрану категорію реципієнтів.

Регулятивна стратегія мовчання. Таке багаторівневе та поліаспектне висловлення, як художній текст, репрезентує також особливий простір неназваного, «знакової тіні», що має значний інтерпретаційний потенціал. Ідеться про стратегію мовчання, номінованого в науковій літературі комунікативно значущим, «мовчанням про щось», «мовчанням замість говоріння», «нульовим замісником вербальної реакції», що сприяє уведенню читача в текст, провокує вгадування реального та прихованого змісту написаного, який інтерпретується врешті-решт «залежно від конкретної ситуації, змісту, ілокутивної функції попереднього висловлення або тексту» (Ваtsevyсh 211). Регулятивною тактикою стратегії мовчання $є$ невербальне вираження змісту, посилене графіко-акцентуаційним контрастуванням: Рєпін підстрибнув зі стільця: - Еге, це иікаво, цікаво... ие добре... ие я вже бачив... о, який каламарик...ие для писаря? (Брати Капранови. Справа сивого).

Залежно від інтенції та ідіостилю автора регулятивна стратегія може бути слабкою чи сильною, експліцитною чи імпліцитною, однорідною чи неоднорідною. Найпростішою й достатньо дієвою щодо реалізації основних комунікативних стратегій, звичайно, постає сильна, експліцитна, однорідна регулятивна стратегія. В оповіданні Г. Медвідь «Щасливчик», наприклад, така стратегія втілена в тактиці макроконтекстного синонімічного повтору: щзасливчик - улюбленець долі - Божий помазаник; відбувся синяками та подряпинами - уцілів; повезло - усе добро збереглося, нічого не пропало.

Регулятивна стратегічність художнього тексту, звісно, не гарант, а лише передумова його адекватного сприйняття. Варто погодитися з думкою М. Бахтіна, що «активність того, хто відкривається», потребує «активності того, хто розуміє», і лише разом вони можуть створити умови найважливішої естетичної події - «зустрічі автора з читачем» (Bakhtin).

Отже, спостереження за регулятивними стратегіями в сучасному українському художньому тексті вможливило їх класифікацію та виявлення основних їхніх тактик. Метою майбутніх студій, безперечно, має стати вдокладнений опис виокремлених регулятивних стратегій.

\section{References}

1. Arnold, I. V. Stilistika. Sovremennyy angliyskiy yazyk (Stylistics. The modern English language). Moskva: Flinta; Nauka, 2002. Print.

2. Bakhtin, M. M. Voprosy literatury i estetiki. Issledovaniya raznykh let (Questions of literature and aesthetics. The different years studies). Moskva: Khudozhestvennaya literatura, 1975. Print.

3. Batsevych, F. S. Vstup do linhvistychnoyi prahmatyky (Introduction to linguistic pragmatics). Kyiv: Vydavnychyy tsentr «Akademiya», 2011. Print.

4. Giles, H., and T. Ogay. "Communication Accomodation Theory". Explaining communication: Contemporary theories and exemplars / B. B. Whaley and W. Samter (Eds.). Mahwah, NJ: Lawrence Erlbaum, 2007. Print.

5. Hrynya, Nataliya. "Kontrast yak semantyko-funktsional'na katehoriya tekstu (na materiali leksykohrafichnykh dzherel ta linhvistychnykh uchen') (Contrast semantically functioning category of a text (on the basis of lexicographic sources and linguistical studies)". Visnyk L'vivs'koho universytetu. Seriya inozemni movy (Visnyk of the Lviv University. Series Foreign Languages) 19 (2012): 86-93.

6. Issers, O. S. Kommunikativnye strategii i taktiki russkoj rechi (Communicative Strategies and Tactics in Russian Speech). Moscow: LKI, 2008.Print.

7. Khaym, D. Kh. "Etnografiya rechi (The speech ethnography)". Novoe v lingvistike (New in linguistics) VII (1975): 156-174. Print.

8. Klyuev, E. V. Rechevaya kommunikatsiya (Speech communication). Moscow: Ripol klassik, 2002. Print.

9. Kosmeda, T. A., and O. V. Khaliman. Movna hra v paradyhmi interpretatyvnoyi linhvistyky. Hramatyka otsinky. Hramatychna ihrema (teoretychne osmyslennya dyskursyvnoyi praktyky) (Language game in the paradigm of interpretative linguistics. Grammar of evaluation. Grammar game unit (theoretical understanding of discursive practice). Drohobych: Kolo, 2013. Print.

10. Krupa, Mariya. Linhvistychnyy analiz khudozhn'oho tekstu (Literary text linguistic analysis). Ternopil': Pidruchnyky i posibnyky, 2005. Print.

11. Larin, B. A. Filologicheskoe naslediye (Philological heritage). SPb., 2003. Print.

12. Levchuk, A. "Zasoby hrafichnoho oformlennya tekstu ta yikh vplyv na intymizatsiyu (The text graphic design means and their influence on intimization)". Aktual'ni pytannya inozemnoyi filolohiyi (Actual issues of foreign philology) 2 (2015): 122-127. Print.

13. Moskovin, V. P. "O priyemakh smyslovogo aktsentirovaniya (About methods of semantic emphasis)". Russkaya rech (Russian speech) 2 (2006): 30-42. Print.

14. Norman, B. Yu. Igra na granyakh yazyka (The game on the language edges). Moskwa: Flinta; Nauka. 2006. Print. 
15. Russkaya razgovornaya rech: Fonetika. Morfologiya. Leksika. Zhest / pod red. E. A. Zemskoj (Russian colloquial speech: Phonetics. Morphology. Vocabulary. Gesture). Moskva: Nauka, 1983. Print.

16. Shevchuk, L. V. Formuvannya movnykh zasobiv komichnoho $v$ suchasniy satyri: tradytsiyi $i$ novatorstvo (Comic linguistic means formation in modern satire: traditions and innovation). Odesa, 1991. Print.

17. Zimnjaja, I. A. "Smyslovoe vosprijatie rechevogo soobshhenija (Semantic perception of the speech message)". Smyslovoe vosprijatie rechevogo soobshhenija (v uslovijah massovoj kommunikacii) (Semantic perception of the speech message (in mass communication)). Moscow: Nauka, 1976: 5-33. Print.

\section{REGULATORY STRATEGIES AND TACTICS IN MODERN UKRAINIAN FICTION}

Svitlana Halaur

Chair of Ukrainian Language, Poltava V. G. Korolenko National Pegagogical University, Poltava, Ukraine

Abstract

Background: Studies of regulatory strategies and tactics in modern Ukrainian prose is relevant because it touches upon the problems of the message special artistic treatment by the addresser for effective mutual understanding with the recipient in terms of asynchronous communication, the explication of heuristic intentional program, planning the author`s discursive interaction with the reader, aimed at transforming the world model of the latter.

Purpose: The studies goal is to classify regulatory strategies in Ukrainian contemporary fiction and identify their main tactics.

Results: The speech act optimal design in artistic prose text which is the most adequately meets the specific communicative situation requirements determines such regulatory strategies: consistent-converging, paradoxical-contrastive, a language game, speech portraying, targeting, silence. The consistent-converging strategy embodied in microcontext and macrocontext repetition and convergence tactics reflects the semantic perception and speech signal processing levels most fully. As one of the dominant expressive features of a literary work, its communicative focus is contrast, then paradoxicalcontrastive strategy is common with its tactics of phonetic-emphasising, lexical-emphasising, grammar-emphasising and graphic-emphasizing-contrast. The language game strategy and its tactics of deliberate language canon abuse are increasingly popularised among writers. Balancing on the verge of rules and creatively filling language gaps, authors, using this strategy, seem to make the language system ideal. Text communicative multidimensionality is the result of a speech portraying strategy that is implemented through tactics of speech opposition or speech polyphony at the level of the author / character identity semantic embodiment. The targeting strategy is represented in the main tactics of the dialogue modelling with an imaginary reader, and the strategy of silence is shown in the tactics of nonverbal content expression.

Discussion: Selected strategies and tactics require more detailed description. In view of artistic communication difficulty, diversity and non-rigidness such regulatory strategies and tactics ranking does not purport to be exhaustive. technique.

Key words: literary communication, communication strategy, regulatory strategy, regulatory tactics, regulatory

Надійшла до редакції 4 березня 2019 року.

DOI 10.31558/1815-3070.2019.37.15

УДК 81 '26

\section{ОБ’ЄКТИВНО-ТЕКСТОВІ ВИМІРИ СТАНДАРТИЗАЦЇ̈ ТА ЕКСПРЕСИВНОСТІ: МЕЖІ МОЖЛИВОГО ${ }^{1}$}

Розглянуто співвідношення стандартизачії та експресивності в межах художнього тексту, схарактеризовано їх симетрійність та асиметрійність з опертям на дискурсивні практики, виявлено основні / неосновні засоби вираження експресивності, рівні такої експресивності, напрями посилення експресивності в художньому тексті, витворення полів експресивної епатажності з концентрованим наповненням тексту відповідними лексичними засобами. 3'ясовано корелятивність експресивності зі стильовими течіями.

Ключові слова: текст, стандартизація тексту, експресивізація тексту, емоційність, експресивний засіб.

The correlation between standardization and expressiveness within the framework of the literary text is considered, its symmetry and asymmetry, supported bythe discursive practices, are characterized, main / non-main means of expressing expressiveness, levels of such expressiveness, directions of intensification of expressiveness in the literary text, creation of fields of expressive shock value with a concentrated content of the text by the corresponding lexical means. The correlation of expressiveness with the stylistic ideas is revealed.

Key words: text, text standardization, text expressiveness, emotionality, expressive means.

\footnotetext{
${ }^{1}$ Дослідження виконано в межах фундаментального наукового проекту “Об’єктивна і суб'єктивна мовносоціумна граматика : комунікативно-когнітивний та прагматико-лінгвокомп’ютерний виміри” (0118U003137).
}

(C) Загнітко А. П., 2019 